\title{
CD19 Expressing Cell Count
}

National Cancer Institute

\section{Source}

National Cancer Institute. CD19 Expressing Cell Count. NCI Thesaurus. Code C103808.

The determination of the amount of the CD19 expressing cells in a sample. 